
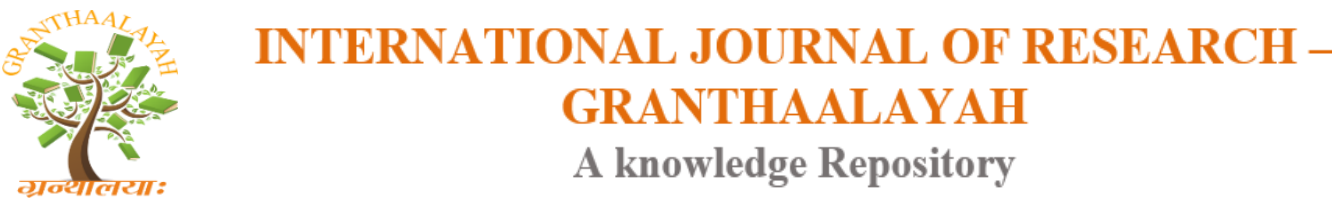

Science

\title{
EMPOWERMENT OF WOMEN THROUGH AYURVEDA (AYURVEDA- A RAY OF LIGHT FOR THE WOMEN TRAPPED BETWEEN TRADITION AND MODERNITY)
}

\author{
Dr. Nishi Arora ${ }^{1}$, Dr. Nidhi Srivastava ${ }^{2}$ \\ ${ }^{1}$ Associate Professor, Maulik Siddhant and Samhita Vibhaag, A \& U Tibbia College and \\ Hospital, Karol Bagh, New Delhi, India \\ ${ }^{2}$ Associate Professor, Head Department of Shaarira Rachana Government Ayurveda College, \\ Jabalpur, India
}

\begin{abstract}
Woman is the centre of any social system. She plays many roles in her life but it is strange, that she has to fight for each single moment for her survival. Time has changed the situation for women on the basis of official recognition but in reality, there are still many persistent conflicts hanging on a thin strand with similar strength to that of a hair.

Keywords: Tradition; Modernity; Conflict; Swasthyasarankshan; Sadachara; Satvavajaya.

Cite This Article: Dr. Nishi Arora, and Dr. Nidhi Srivastava. (2017). "EMPOWERMENT OF WOMEN THROUGH AYURVEDA (AYURVEDA- A RAY OF LIGHT FOR THE WOMEN TRAPPED BETWEEN TRADITION AND MODERNITY).” International Journal of Research - Granthaalayah, 5(9), 95-98. https://doi.org/10.29121/granthaalayah.v5.i9.2017.2206.
\end{abstract}

\section{Introduction}

First of all, the definition of conflict should be known. Conflict is a serious disagreement or argument, typically a protracted one. Here, it is very necessary to know the meaning of tradition and modernity too. Tradition is a belief or behavior passed through customs from generation to generation. Modernity is a way of thinking by the standards of a modern viewpoint. The main problem that woman seems to face in contemporary Indian society is that she is stuck between the two ideas of modernity and tradition. The differences between Indian women's culture, their aspirations and self-esteem are quite large. They have been through a tough struggle both at personal and social level since ages and have continued to be differentiated. Women have suffered through the ages where males had dominated, discriminated and repressed, being treated like animals and objects of enjoyment.

The purpose of explaining about all that is said above is to understand why it has become mandatory to take about this burning issue of finding the identity and dignity of women in the patriarch society. When even the most excellent ways out in the world are losing their charm, or 
are being proved insufficient to solve this grave question, Ayurveda is slowly getting leaned over by many of the women in the world as it provides the most optimal path. Ayurveda believes that a healthy body is the preliminary condition of a healthy mind. A healthy person is happy and is confident enough to work for self and the society. This paper endeavors to suggest the ways of becoming healthy. Light will be thrown on Svasthya Sanrakshana, Sadachara and urges to be controlled or to be expelled out including Sattvavajaya.

\section{Material and Methods}

It was explored through basic Ayurvedic texts i.e. Samhitas about various ways of Swasthya Sarakshana, and it was found that life style modification is the main factor that decides anyone's health state. The concept of Dinacharya (The Daily Routine) and Ritucharya (the diet and action variations according to season), Sadachara (The following up of ethical and novel duties) and knowing about urges that must be controlled (Dharaneya) and the ones that do not (Adharaneya), all these come under the principle of life style modification. Satavajaya Chikitsa is another important theory which works upon well-being of the human mind.

\section{सत्त्वावाजयः- पुनर्हितेभ्यो र्थेभ्यो मनोनिग्रहः(Ch.Su.11/54)}

It means to keep mind away from arbitrary thoughts that negatively affect all perceptions.

The need to explain these basics is not felt here as it is being presented before all knowledgeable people of Ayurveda. While describing the importance of following guidelines of Dinacharya, Acharya Charaka said that

$$
\begin{aligned}
& \text { नगरी नगरस्येव रथस्येव रथी यथा| } \\
& \text { स्वशरीरस्य मेधावी कृत्येष्ववहितो भवेत्|| (Ch.Su. /103) }
\end{aligned}
$$

This verse means that a person should take care of self as if they were a king of a place or an owner of a vehicle cares for their ruled states or vehicle respectively.

Similarly, benefits of following the Ritucharya, Acharaya Charaka had been explained beautifully-

$$
\begin{aligned}
& \text { तस्याशिताद्यादाहारदबलम् वर्णश्च वर्धते| } \\
& \text { यस्यर्तुसात्म्यं विदित चेश्ताहारव्यपाश्रयम्| (Ch.Su.6/3) }
\end{aligned}
$$

Here Acharya clearly says that when food is consumed and activities are done according to the seasonal variations, people's Bala and Varna increases. Chakrapani further told that Bala \& Varna represent state of true Dhatusara. It is also to be noted that womens' menstrual cycle is explained with the word Ritucharya in Sushrut Samhita

ऋतुस्तु द्वादश रात्रं भवति दुष्तार्तवः (Su.Sh.) 
As during these three days in the beginning and last 16 days of the cycle, the uterine os remains constricted. So, these 12 days are best for healthy conception. It is also suggested that during the days of menstruation it is better to take milk, cooked Yavaka in minimum amount to achieve the state of Koshth Shodhanakarshana. But here it is emphasized by Acharya Arundatta that only koshta shodhan and karshana must be there and not Karshana of other parts of body, as it is done in virechan process through Trivritta etc.

Further, the value of not suppressing certain urges/ Adharneeya vega is told in the Sadvritta and also about the urges to be suppressed are told, special focus was given to Sadachara as referred in the following text-

\section{तस्मादात्महितं चिकीर्षता सर्वेण सर्वम् सर्वदा समृतिमास्थाय सद्वृत्तमनुष्ठेयं। (ch.su.8/17) and also तद्यनुतिष्ठन् युगपत् संपादयत्यर्थद्वयमारोग्यमिन्द्रियविजयं चेति॥}

They found that following up of ethical values and keeping standards help living a happy and balanced life.

Discussion- After reintroducing the well-known preventive measures of Ayurveda, it is to be discussed here that how these measures are going to help in promoting and strengthening women. Dinacharya and Ritucharya are 2 ways which include the regulation of diet and conduct during the day, keeping in mind about the seasonal variations. The habit of time-management inculcates automatically with following up of above principles. It also helps in having a balanced diet, keeping sedentary lifestyle away thus preventing metabolic disturbance and diseases. A healthy woman may not only work more but with more vigor. It develops self-confidence and improve self- esteem of women. The follow up of the dietary pattern during menstruation reduces her agony and discomfort considerably in those days. Resultantly, she may work tirelessly and without unnecessarily hampering her routine. This also makes her feel free and satisfied.

The urges which are not to be suppressed, when suppressed become the reason for many diseases. When a female, who normally suppresses these either due to shame or social norms, comes out of the orthodox attitude and decides to flush away the natural urges at right time, she feels relaxed and calm. Moreover, it is also a step towards thinking about self without giving undue concern to the people or society around.

Sadachar or moral and ethical values, are always a nice way to remain mindful about our activities and promotes better understanding about reality of life. So, must of the undue worries may be kept away with this? Last but not the least is Satvavajaya(counselling).

It is needed to empower everyone and especially, women because they remain more apprehensive about the normal incidents. This is due to their social status and lesser education, particularly in India. A good counsellor may work at cognition level to improve women's quality of life and develop more courage to face the challenges of life. 


\section{Conclusion}

It is concluded that even though Ayurveda has not given much information about women's troubles, if a non-conventional thought process can be initiated towards implementing basic principles of Ayurveda to women, a lot is there about empowering them. Gender sanitization is another issue, which has to be discussed openly to achieve this goal.

\section{References}

[1] Charak Samhita

[2] Sushrut Samhita

[3] Deshpande, Shashi. Small Remedies, New Delhi: Penguin, 2000Print.

[4] Gerein, James. Rev on Small Remedies. World Literature Today. Vol.74, No.4. Autumn 2000 